\title{
Scalpel cuts to the soul
}

\author{
Alternative Medicine \\ Rafael Campo \\ Duke University Press; 2013
}

$\mathrm{D}$ r. Rafael Campo's poems are precise and incisive. You measure their beats as if listening through a stethoscope. You feel the scalpel cut through to your soul eschewing anesthesia because you want to be awake and alert for Campo's kind of surgical intervention. He slices through the facade of your life to pull back layers of skin and mores to the core mystery of the purpose of your body. "I see the outline of the soul you shield," he writes in "Primary Care," a poem of apostrophe that begins:

You, body, bleed, you stink, you interrupt with plaintive sounds as if we didn't know you suffer ...

... when you bleed

and when you stink, it's god's grief that we smell.

The blood, the stink, the grief of god, the suffering that Campo sees and feels in his patients serve to "remind us that we suffer, yes, remind/us that we must, or else we never lived."

In Alternative Medicine, Campo's sixth collection of poetry, he continues to pound his readers with his autonomic iambic rhythms in poems about the functions and malfunctions of living and dying, about what happens when you step outside the norms of health, race or sexual preference - matters over which you have no control.

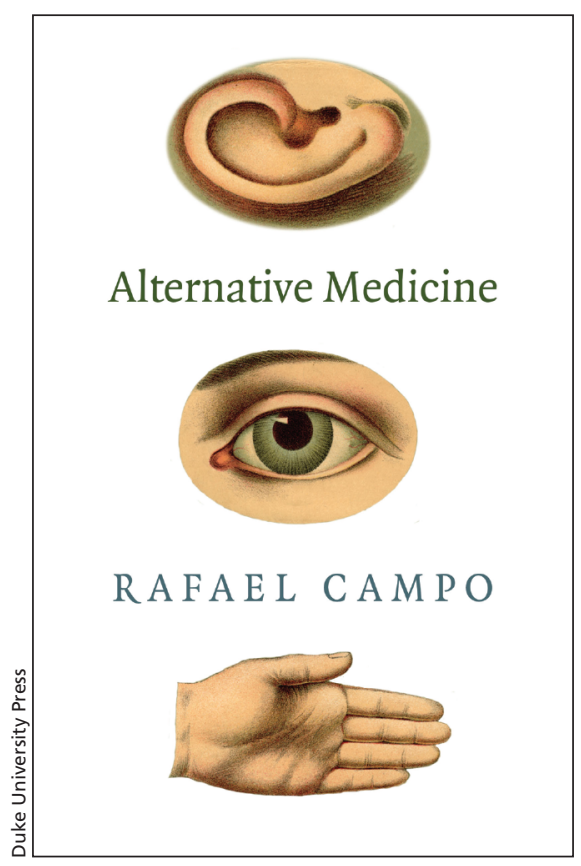

In Campo's world, you suffer alone. You die alone. Those experiences are impossible to share with others. In Campo's world, you survive alone in a world that for the most part is absent of empathy. In "Recent Past Events," the anaphora of the early days of the AIDS epidemic, "we feared their blood" becomes the anthem of the medical staff who treat patients dying all around them of horrifying immunesystem collapses.

In "The Performance," a party at a pediatric cancer ward becomes a view of children who "looked just like/a dozen blighted eggs, bald heads/shining, the sun on them too bright/as if a miracle were near."
But the doctor sees this party with clowns, balloons, "and green sherbet melting, like them/not long for this world." The punch, the cookies make him and the nurses "happy [they] could savor what [they] knew, in spite/of what [they] hoped, was cruel joy."

But Campo is not only the cold observer. He is also fearlessly compassionate. In "Faith Healing," as he palpates a woman in extremis whose "lymphoma drenched/her in cold sweats," Campo is surrounded as "the dead /moved quietly around the room, unseen," and the vision moves him to cry out, "Dear Lord/forgive me for not healing them."

In Campo's world, where always "someone is dying alone in the night," he regrets so many he cannot save, but in the end, hopes that "someone is dying in peace in the night."

In the face of such battering by the downside of life, Campo knows what he's thankful for:

There is suffering, yes, but there is peace ... I grasp at last what I'm still thankful for: not the disease that lets me comfort her,

or my unexceptional abilities however insufficient they might be,

but in the final absence of a cure, the need in all of us for someone's care.

Tom Lombardo MS MFA

Poetry series editor

Press 53

Atlanta, Ga.

CMAJ 2014. DOI:10.1503/cmaj.140077 